$\mathrm{UH}$

iti

Universität Hamburg
Faculty Economics

and Social Sciences

Chair for Economic Policy

T. FALCH / J.A.V. FISCHER

\title{
PUBLIC SECTOR DECENTRALIZATION AND
}

\section{SCHOOL PERFORMANCE: INTERNATIONAL}

EVIDENCE

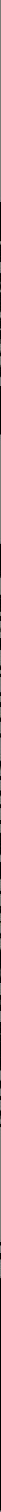


Hamburg Contemporary Economic Discussions University of Hamburg Faculty Economics and Social Science Chair for Economic Policy Von-Melle-Park 5 D-20146 Hamburg | Germany Tel $+494042838-4622$ $\mathrm{Fax}+494042838-6251$ http://www.uni-hamburg.de/economicpolicy/

Editor: Wolfgang Maennig

Torberg Falch

Norwegian University of Science and Technology Department of Economics

Torberg.Falch@svt.ntnu.no

Justina Fischer

University of Hamburg

Institute for Public Finance

JAVFischer@gmx.de

ISSN 1865 - 2441 (Print)

ISSN 1865 - 7133 (Online)

ISBN 978 - 3 - 940369 - 76 - 5 (Print)

ISBN 978 - 3 - 940369 - 77 - 2 (Online) 


\title{
Public Sector Decentralization and School Performance: International Evidence*
}

\begin{abstract}
Using a panel of international student test scores $1980-2000$ (PISA and TIMSS), panel fixed effects estimates suggest that government spending decentralization is conducive to student performance. The effect does not appear to be mediated through levels of educational spending.

Keywords: Fiscal Decentralization; Student Achievement; Federalism; PISA; TIMSS; Education; School Quality JEL classification: C33; H2; $12 ; \mathrm{H} 4 \mathrm{O}$
\end{abstract}

Version: 28 January 2010

\section{Introduction}

In political economy and public finance, the linkage between government decentralization and the quality of public sector services has been much debated. However, empirical evidence is limited since, in general, the quality of public sector activities is hard to measure, and decentralization varies mainly across countries. In this paper we utilize a country panel based on several comparative international achievement tests of students to quantify the quality of compulsory education, and estimate the effect of public sector spending decentralization within a panel data framework.

Department of Economics, Norwegian University of Science and Technology, Dragvoll, N-7491 Trondheim, Norway, and CESifo, Munich, Germany. E-mail: Torberg.Falch@svt.ntnu.no

++ At time of writing: OECD, Social Policy Division, F-75775 Paris, France and Thurgau Institute for Economics at the University of Konstanz, $\mathrm{CH}-8280$ Kreuzlingen, Switzerland. Current affiliation: University of Hamburg, Institute for Public Finance, Department of Economics, Von-MellePark 5, 20146 Hamburg, Germany. E-mail: javfischer@gmx.de

* We thank Axel Dreher, Lars Feld, Urs Fischbacher, Gebhard Kirchgässner, Christoph Schaltegger, Jan Schnellenbach, Bjarne Strøm, and Roland Vaubel for helpful comments and discussions, and Dan Stegarescu and Daniel Treisman for sharing their data. Torberg Falch thanks the Thurgau Institute for Economics (TWI) at the University of Konstanz for generous hospitality. 


\section{Related Literature}

OATES (1972) argues that, in general, more decentralized political decisionmaking allows better adjustment of (local) supplies to locally heterogeneous demands. In the model of HOXBY (1999), public school productivity is higher with decentralized financing through local property taxes since Tiebout mechanisms reveal important information on local preferences. In SEABRIGHT's (1996) framework with incomplete contracts, the main advantage of decentralization is that it is easier to hold decision-makers accountable. For other, possibly detrimental effects of decentralization, see, e.g., BJØRNSKOV, DREHER, \& FISCHER (2008).

In the economics of education literature, the empirical evidence mainly supports the view that decentralized education systems improve on student achievement. In a cross-country analysis, WÖßMANN (2003) finds that school autonomy exerts a beneficial impact. HOXBY \& ROCKOFF (2004) report that autonomous charter schools perform better than public sector schools in the US, CLARK (2009) identifies a positive effect of a major reform granting larger school autonomy in the U.K. GALIANI \& SCHARGRODSKY (2002) show that the decision to decentralize public education in the early 1990s raised student achievement in Argentina, while NAPER (2010) reports that decentralized hiring of teachers increases school effectiveness in Norway. On the other hand, MERROUCHE (2007) finds that decentralization of education spending responsibility in Spain did not affect the illiteracy rate. Regarding general government decentralization, BARANKAY \& LOCKWOOD (2007) identify for 26 Swiss states a positive effect on the share of high school graduates in the 19-year old population. The literature is inconclusive on whether measures of school spending decentralization just approximate general government decentralization, or whether educational decentralization is important per se.

\section{The Model and Data}

Our empirical model focuses on the relationship between school quality and public sector decentralization. We define school quality in terms of achievement in 
test scores obtained from all six available comparative international achievement tests from 1980 to 2000 assessing students aged 13-15 years. ${ }^{1}$ We use the national average of the scores in mathematics and natural science tests, and standardize them in order to ensure comparability across tests. Our procedure standardizes the test scores for the most frequently participating ("core") countries. For each test, the mean of our adjusted score is set equal to zero with standard deviation of unity within the group of "core" countries. For a given test, the overall average value then depends on the test performance in "non-core" countries, and consequently on which "non-core" countries participated or not. ${ }^{2}$

Decentralization is commonly defined as the percentage of sub-national government spending in general government spending, calculated by the World Bank up to $1999 .{ }^{3}$ KEMAN (2000) and TREISMAN (2000) argue that it is important to distinguish discretion in terms of financial policy implementations by local administrations ('the right to act'), which we measure directly, from local government political autonomy ('the right to decide'), which we capture only indirectly. Any reform in government decentralization may need some time to influence behavior. The size of the lag will depend on to what extent the change in decentralization was expected and student learning is cumulative. We will use a lag of one year in the decentralization variable to account for sluggish responses, but will also present results from models allowing for more lags in the variable of interest.

In addition, the empirical model includes as co-variates GDP per capita, population size, and the size of the public sector that insures against income shocks, particularly government social expenditures and government consumption spending (for sources see FALCH \& FISCHER, 2008a). ${ }^{4}$ Country fixed effects account for

1 We use the results of the SIMS and SISS tests conducted by the International Association for the Evaluation of Educational Achievement (IEA) in 1980-81 and 1983-85, respectively, the IAEP test in 1990-91, IEA's TIMSS tests in 1994-95 and 1998-99, and the OECD PISA test in 2000.

2 For a detailed description of the standardization procedure, see FALCH \& FISCHER (2008a).

3 The index is more closely described in DREHER \& FISCHER (2010).

4 We have also estimated models including the population share with at least a secondary education. The t-value of this variable was always below unity, and values are missing for some observations. 
time-invariant features such as institutions and culture (e.g., the national school system, school autonomy, population preferences, etc.). They are expected to mitigate potential endogeneity biases. We also include a dummy variable for the only OECD PISA test in the regression sample.

The way the dependent variable is constructed is an argument for not including time fixed effects in the baseline model. With time fixed effects, the withincountry variation in student performance would depend on the composition of participating countries in the specific tests. The motivation for the standardizing procedure we apply is exactly to avoid this flaw. However, to assess the robustness of the specification, we test for the presence of time effects.

\section{Tab. 1 Descriptive Statistics}

\begin{tabular}{|c|c|c|c|c|c|}
\hline Variable & Mean & Std. Dev. & $\begin{array}{l}\text { Std. Dev. } \\
\text { within }\end{array}$ & Min & Max \\
\hline Test score & -0.34 & 1.00 & 0.44 & -2.86 & 2.10 \\
\hline Decentralization, lagged & 31.3 & 14.2 & 1.61 & 3.84 & 58.7 \\
\hline Population size (log) & 16.7 & 1.54 & 0.05 & 12.5 & 19.5 \\
\hline GDP per capita (log) & 10.0 & 0.28 & 0.15 & 8.72 & 10.8 \\
\hline Social spending as \% of GDP (log) & 2.95 & 0.28 & 0.09 & 1.76 & 3.48 \\
\hline $\begin{array}{l}\text { Government consumption spending as } \\
\% \text { of GDP (log) }\end{array}$ & 2.94 & 0.20 & 0.06 & 2.41 & 3.39 \\
\hline $\begin{array}{l}\text { Primary educational spending per pupil } \\
\text { (log) }\end{array}$ & 2.86 & 0.30 & 0.16 & 2.14 & 3.74 \\
\hline
\end{tabular}

For reasons of comparability, we restrict the sample to well-established OECD countries (as of 1990) with relatively stable political and administrative systems, excluding the post-communist countries. Table 1 provides descriptive statistics. The standard deviation of the dependent variable is close to unity. On average, local government spending constitutes 31 percent of total government spending, varying from four percent (Greece) to almost 60 percent (Canada). For all va- 
riables, the within-variation seems to be sufficiently large to justify a country fixed effects specification.

\section{Empirical Results}

Table 2 provides the regression outcomes. Column (1) presents the simple correlation between spending decentralization and test score. The relationship is positive but small. The remaining models (columns (2) to column (10)) include country fixed effects.

Comparing the results in columns (1) and (2), we observe that including country fixed effects and covariates increases the size of the effect of decentralization ( 0.021 vs. 0.072$)$ and its significance level (10 percent vs. 5 percent). In the full model (2), the result implies that rising spending decentralization by 10 percentage points increases student test scores by 0.7 standard deviations. This is a nontrivial effect given that three countries in the sample have within-variations in decentralization larger than 5 percentage points.

Model 2 does not include time specific effects as explained above, but a dummy variable for the PISA test of the year 2000, which is highly significant. Notice, however, that if time specific effects are included, they are jointly insignificant. ${ }^{5}$ Column (3) in Table 2 replaces the PISA dummy variable with a time trend, without affecting the coefficient size of decentralization (0.074 vs. 0.072 ). Since the trend is not significant at conventional levels, the remaining models presented include only the PISA dummy variable but exclude the time trend. Excluding any time variable increases the effect of decentralization to 0.088 (column (4)).

5 The p-value on a test for joint significance using the model specification in column (2) in Table 2 is 0.47 . 


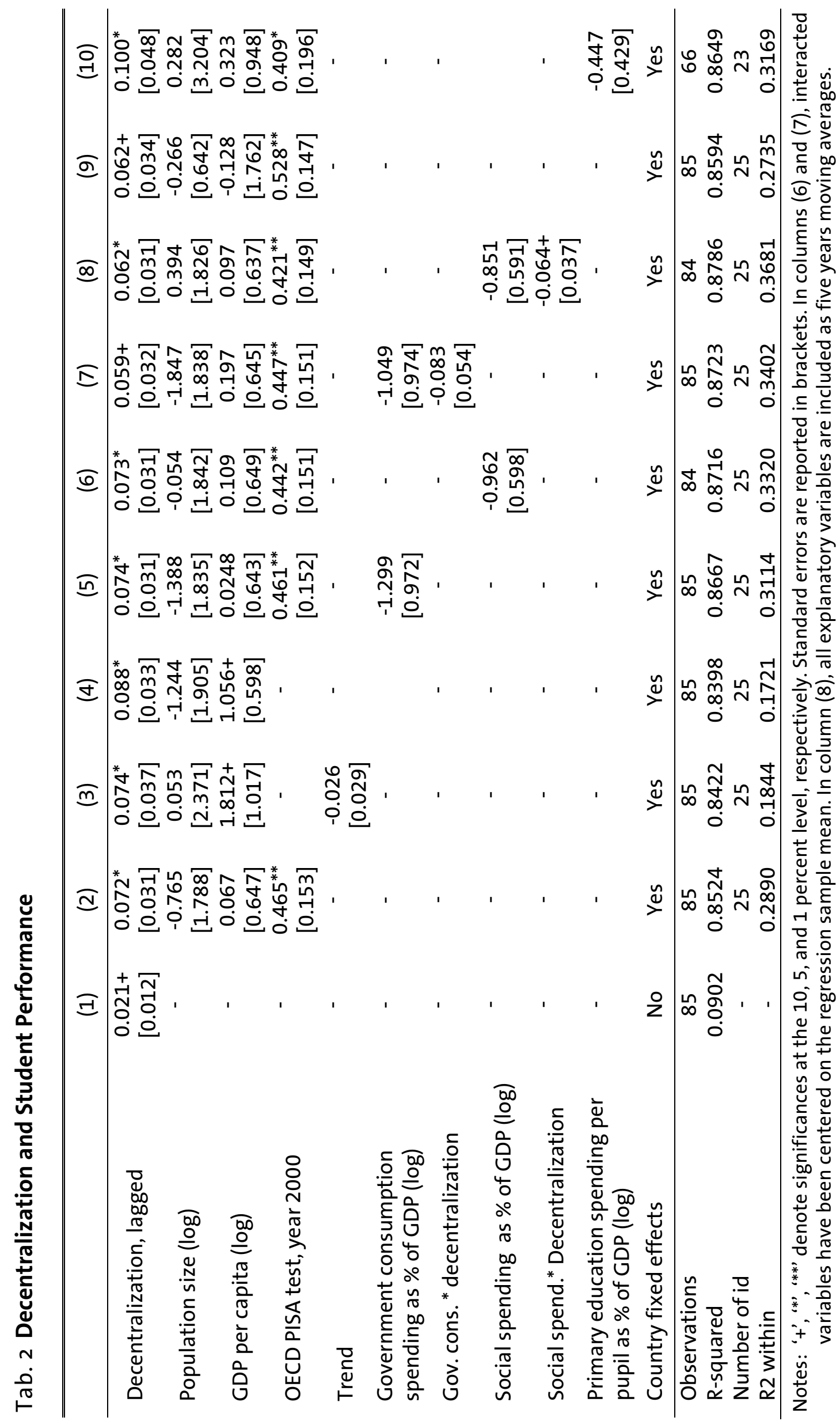


The results in Table 2 also imply that student performance is not affected by GDP or population size. Regarding GDP, there may be an endogeneity problem in the long-run because of a growth enhancing effect of student achievement (Hanushek and Kimko, 2000). However, excluding GDP does not alter the coefficient size of decentralization.

\section{Public Sector Size}

Columns (5) and (6) in Table 2 show that the positive effect of decentralization is robust to the inclusion of public sector size, measured by either total government consumption spending or government social expenditures (0.074 and 0.073, respectively). The effect of decentralization does not appear to be mediated through government spending activities. Both public sector size coefficients are negative and of similar magnitude as reported in FALCH \& FISCHER (2008a), but insignificant, probably due to fewer observations in the present analysis.

Given that decentralization increases student achievement while government size tends to reduce it, one would expect, in line with the finding for life satisfaction in BJФRNSKOV et al. (2008), that decentralization is more advantageous in the case of large governments than with small governments. Columns (7) and (8) add interaction terms between government size and decentralization. Contradicting our hypothesis, both interaction terms are negative. The performanceenhancing effect appears to decline in public sector size. One might speculate whether market distortions through non-internalization of inter-jurisdictional spillovers increase more in decentralized countries than in centralized countries as the government's involvement in the economy rises. The interaction terms are small, however, and only significant at the 10 percent level for social spending. The overall effect of decentralization is positive for the within-sample variation in social expenditures, for which it varies from 0.05 to $0.08 .^{6}$

6 The estimated coefficients can readily be interpreted because all interacted variables are centered. For centered log of social spending the within-variation ranges from -0.248 to 0.198. 


\section{Robustness tests on decentralization}

One may suspect that the small within-country variation in the decentralization measure is due to minor changes in, e.g., accounting rules rather than changes in the real economy. However, some of the variation is clearly real. For example, the dip in decentralization by 3.5 percentage points in Germany in 1991 is a unification effect: The East German Laender were fiscally far less autonomous than the West German Laender. The continuous decline from 1991 on reflects the growing dependence of the East German Laender on federal transfers. The ongoing decrease in decentralization in Switzerland from 1990 on by roughly 0.5 percentage points per year seems to be related to continuously rising unemployment and old-age pension expenditures at the federal level. Sweden experienced relatively large fluctuations in decentralization in the 1990s related to the major recession at the start of the decade and the governmental reforms that followed it. We have estimated the model on subsamples of countries with relatively small and large changes in decentralization, and find that the effect of decentralization is stable. $^{7}$

The response time of student performance to changes in decentralization is not clear from economic theory, but one might expect that some time passes by before structural changes start having an effect. The model in column (9) of Table 2 uses five year moving averages of all explanatory variables. This specification also smoothes out minor fluctuations in the decentralization measure due to, e.g., changes in accounting rules. The effect of decentralization is now slightly smaller (0.062), but still significant at the 10 percent level. When testing for a more sluggish response to changes in fiscal decentralization, employing a three-year (twoyear) lag of the variable of interest, we obtain a coefficient of 0.052 (0.062) (both significant at the 5 percent level, not reported).

Five countries have within-country standard deviation in decentralization above 2.5 in the regression sample (Sweden, USA, Iceland, Switzerland, and Germany). For this subsample of 17 observations, the coefficient (standard error) of decentralization is $0.088(0.048)$. For the other countries (68 observations), the coefficient is 0.066 (0.046), and a statistical test cannot reject that the coefficients are equal ( $p$-value of 0.74). When the sample is split into two equal-sized sub-samples of countries with small and large within-country variation in decentralization, the coefficients are $0.071(0.074)$ and 0.083 (0.039), respectively. 
Column (10) in Table 2 investigates one potential transmission channel for the effect of spending decentralization. We test the hypothesis that decentralization influences student performance through public expenditures levels in compulsory education (e.g. Fischer, 2005). Column (10) adds to model (2) primary school expenditures per pupil as percent of $G D P^{8}$, but the effect is clearly insignificant. In contrast, the coefficient of decentralization stays significant (0.100), indicating that its effect is not transmitted through educational spending. ${ }^{9}$

\section{Conclusion}

A panel data analysis of international student test scores suggests that government spending decentralization is beneficial to student performance. This general decentralization effect appears not to be mediated by levels of educational spending. Our analysis also suggests that this advantageous effect decreases in public sector size. However, further research appears necessary on the transmission mechanisms through which the positive effect of local policy implementation works.

\section{References}

BARANKAY, I. \& B. LOCKWOOD (2007). Decentralization and the productive efficiency of government: Evidence from Swiss cantons. Journal of Public Economics 91, 1197-1218.

BJØRNSKOV, C., A. DREHER, \& J.A.V. FISCHER (2008). On decentralization and life satisfaction. Economics Letters 99, 147-151.

CLARK, D. (2009). The performance and competitive effects of school autonomy. Journal of Political Economy 117, 745-783.

8 This data are obtained from the World Bank education database. In this database, there is much less observations for secondary education than for primary education.

9 In principle, fiscal spending decentralization may only approximate decentralization of government spending on education, a finding that would be in congruence with the school autonomy effects referred above (section 2). Unfortunately, a measure for education spending decentralization is only available from 1997 on, which makes a thorough test of the hypothesis impossible. However, the preliminary findings in FALCH \& FISCHER (2008b) suggest that it is general decentralization and not school decentralization which matters. 
DREHER, A. \& J.A.V. FISCHER (2010). Government decentralization as a disincentive for transnational terror? An empirical test. International Economic Review, 2010, forthcoming.

FALCH, T., \& J.A.V. FISCHER (2008a). Does a generous welfare state crowd out student achievement? Panel data evidence from international student tests. CESifo Working Paper 2383.

FALCH, T., \& J.A.V. FISCHER (2008b). Public sector decentralization and school performance: International evidence. TWI Research Paper Series 39, University of Konstanz.

FISCHER, J.A.V. (2005). Do institutions of direct democracy tame the leviathan? Swiss evidence on the structure of expenditure for public education. CESifo Working Paper Series, CESifo Working Paper 1628.

GALIANI, S. \& E. SCHARGRODSKY (2002). Evaluating the impact of school decentralization on educational quality. Economía LACEA 2, no. 2:275-314.

HANUSHEK, E.A., \& D.D. KIMKO (2000). Schooling, labor-force quality, and the growth of nations. American Economic Review 90, 1184-1208.

HOXBY, C. (1999). The productivity of schools and other local public goods producers. Journal of Public Economics, 74, 1-30.

HOXBY, C. M. \& J. E. ROCKOFF (2004). The impact of charter schools on student achievement (mimeo), November.

KEMAN, H. (2000). Federalism and policy performance. A conceptual and empirical inquiry, in: U. Wachendorfer-Schmidt (Ed.), Federalism and political performance (Routledge, London)

MERROUCHE, O. (2007). The long term effect of education spending decentralization on human capital in Spain. Working Paper Series Uppsala University, Department of Economics, 2007:3.

NAPER, L. R. (2010). Teacher hiring practice and educational efficiency. Economics of Education Review, forthcoming.

OATES, W.E. (1972). Fiscal federalism. Harcourt Brace Jovanovich: New York.

SEABRIGHT, P. (1996). Accountability and decentralisation in governments: An incomplete contracts model. European Economic Review 40, 61-89.

TREISMAN, D. (2000). Decentralization and the quality of government. Working paper, Department of Political Science, University of California, Los Angeles.

WÖßMANN, L. (2003). Schooling resources, educational institutions and student performance: The international evidence. Oxford Bulletin of Economics and Statistics 65, 117170. 


\section{Hamburg Contemporary Economic Discussions}

(Download: http://www.uni-hamburg.de/economicpolicy/discussions.html)

01/2005 FEDDERSEN, A. / MAENNIG, W.: Trends in Competitive Balance: Is there Evidence for Growing Imbalance in Professional Sport Leagues?, January 2005.

02/2005 SIEVERS, T.: Information-driven Clustering - An Alternative to the Knowledge Spillover Story, February 2005.

03/2005 SIEVERS, T.: A Vector-based Approach to Modeling Knowledge in Economics, February 2005.

04/2005 BUETTNER, N. / MAENNIG, W. / MENSSEN, M.: Zur Ableitung einfacher Multiplikatoren für die Planung von Infrastrukturkosten anhand der Aufwendungen für Sportstätten - eine Untersuchung anhand der Fußball-WM 2006, May 2005.

01/2006 FEDDERSEN, A.: Economic Consequences of the UEFA Champions League for National Championships - The Case of Germany, May 2006.

02/2006 FEDDERSEN, A.: Measuring Between-season Competitive Balance with Markov Chains, July 2006.

03/2006 FEDDERSEN, A. / VÖPEL, H.: Staatliche Hilfen für Profifußballclubs in finanziellen Notlagen? - Die Kommunen im Konflikt zwischen Imageeffekten und Moral-Hazard-Problemen, September 2006.

04/2006 MAENNIG, W. / SCHWARTHOFF, F.: Stadium Architecture and Regional Economic Development: International Experience and the Plans of Durban, October 2006. 


\section{Hamburg Contemporary Economic Discussions}

(Download: http://www.uni-hamburg.de/economicpolicy/discussions.html)

01

02

03

04

05

06

07

08

09

10

11

12

13

AHLFELDT, G. / MAENNIG, W.: The Role of Architecture on Urban Revitalization: The Case of "Olympic Arenas" in Berlin-Prenzlauer Berg, 2007.

FEDDERSEN, A. / MAENNIG, W. / ZIMMERMANN, P.: How to Win the Olympic Games - The Empirics of Key Success Factors of Olympic Bids, 2007.

AHLFELDT, G. / MAENNIG, W.: The Impact of Sports Arenas on Land Values: Evidence from Berlin, 2007.

DU PLESSIS, S. / MAENNIG, W.: World Cup 2010: South African Economic Perspectives and Policy Challenges Informed by the Experience of Germany 2006, 2007.

HEYNE, M. / MAENNIG, W. / SUESSMUTH, B.: Mega-sporting Events as Experience Goods, 2007.

DUST, L. I MAENNIG, W.: Shrinking and Growing Metropolitan Areas - Asymmetric Real Estate Price Reactions? The Case of German Single-family Houses, 2007.

JASMAND, S. / MAENNIG, W.: Regional Income and Employment Effects of the 1972 Munich Olympic Summer Games, 2007.

HAGN, F. / MAENNIG W.: Labour Market Effects of the 2006 Soccer World Cup in Germany, 2007.

HAGN, F. / MAENNIG, W.: Employment Effects of the World Cup 1974 in Germany.

MAENNIG, W.: One Year Later: A Re-appraisal of the Economics of the 2006 Soccer World Cup, 2007.

AHLFELDT, G., MAENNIG, W.: Assessing External Effects of City Airports: Land Values in Berlin, 2007.

AHLFELDT, G.: If Alonso was Right: Accessibility as Determinant for Attractiveness of Urban Location, 2007.

AHLFELDT, G.: A New Central Station for a Unified City: Predicting Impact on Property Prices for Urban Railway Network Extension, 2007. 


\section{Hamburg Contemporary Economic Discussions}

(Download: http://www.uni-hamburg.de/economicpolicy/discussions.html)

FEDDERSEN, A. / MAENNIG, W.: Arenas vs. Multifunctional Stadia Which Do Spectators Prefer?, 2007.

AHLFELDT, G. / FEDDERSEN, A.: Geography of a Sports Metropolis, 2007.

FEDDERSEN, A. / GRÖTZINGER, A. / MAENNIG, W.: New Stadia and Regional Economic Development - Evidence from FIFA World Cup 2006 Stadia, 2008.

AHLFELDT, G. / MAENNIG, W.: Monumental Protection: Internal and External Price Effects, 2008.

MAENNIG, W. / PORSCHE, M.: The Feel-good Effect at Mega Sport Events - Recommendations for Public and Private Administration Informed by the Experience of the FIFA World Cup 2006, 2008.

AHLFELDT, G.: The Train has Left the Station: Real Estate Price Effects of Mainline Realignment in Berlin, 2008.

MAENNIG, W. I WELLBROCK, C.-M.: Sozio-ökonomische Schätzungen Olympischer Medaillengewinne: Analyse-, Prognose- und Benchmarkmöglichkeiten, 2008.

MAENNIG, W. / ALLERMS, S.: South Africa 2010: Economic Scope and Limits, 2008.

AHLFELDT, G. / FEDDERSEN, A.: Determinants of Spatial Weights in Spatial Wage Equations: A Sensitivity Analysis, 2008.

AHLFELDT, G. / WENDLAND, N.: Fifty Years of Urban Accessibility: The Impact of Urban Railway Network on the Land Gradient in Industrializing Berlin, 2008.

AHLFELDT, G. / FRANKE, B. / MAENNIG, W.: Terrorism and the Regional and Religious Risk Perception of Foreigners: The Case of German Tourists, 2009.

FEDDERSEN, A. / MAENNIG, W.: Wage and Employment Effects of the Olympic Games in Atlanta 1996 Reconsidered, 2009.

AHLFELDT, G. I MAENNIG, W.: Impact of Non-Smoking Ordinances on Hospitality Revenues: The Case of Germany, 2009. 

On the Relation Between Income Inequality and Happiness: Do Fairness Perceptions Matter?, 2009.

AHLFELDT, G. / MAENNIG, W. / OSTERHEIDER, T.: Regional and sectoral effects of a common monetary policy: evidence from Euro Referenda in Denmark and Sweden, 2009. FEDDERSEN, A. / JACOBSEN, S. / MAENNIG, W.: Sports Heroes and Mass Sports Participation - The (Double) Paradox of the "German Tennis Boom", 2009. AHLFELDT, G. / MAENNIG, W. / ÖLSCHLÄGER, M.: Lifestyles and Preferences for (Public) Goods: Professional Football in Munich, 2009. FALCH, T. / FISCHER, J.A.V.: Public Sector Decentralization and School Performance: International Evidence, 2010. 


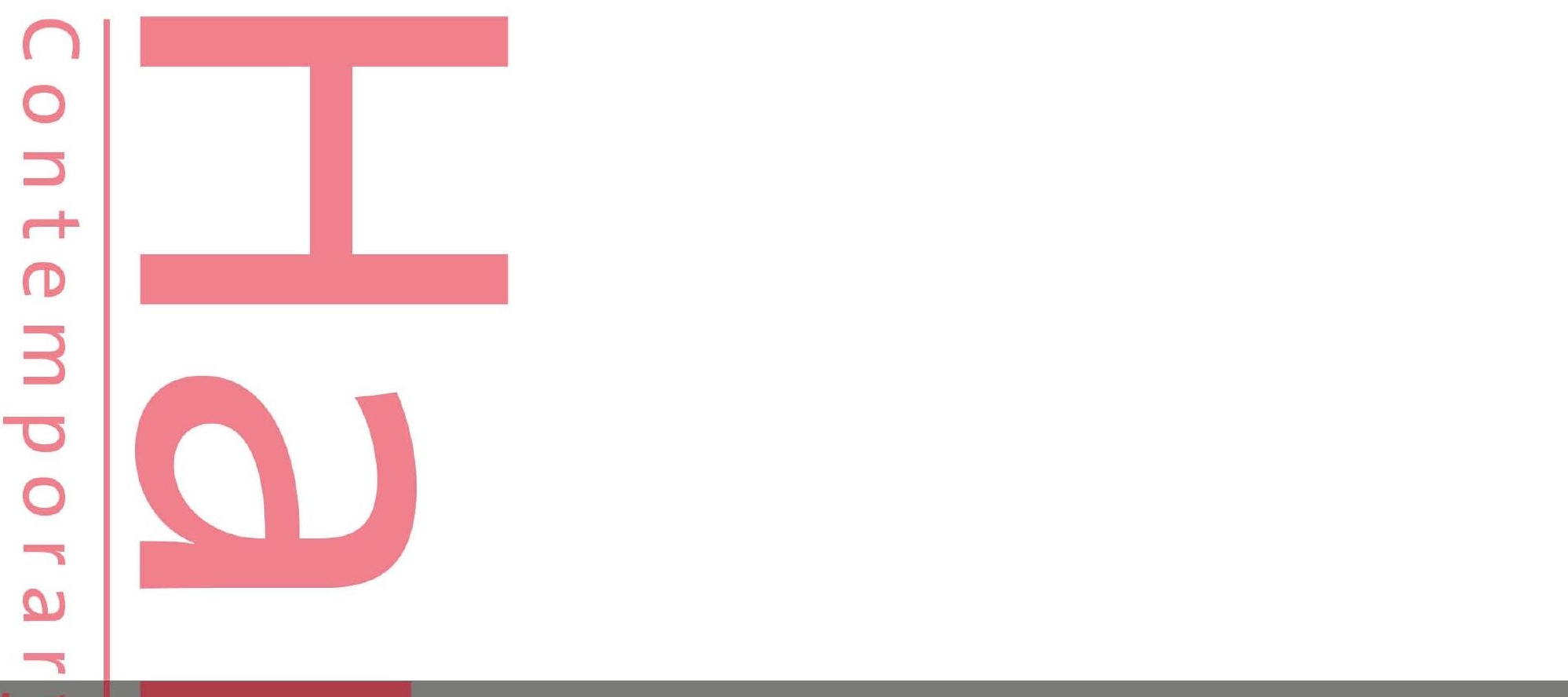

ISSN 1865-2441 (PRINT) ISSN $1865-7133$ (ONLINE)

ISBN 978-3-940369-76-5 (PRINT) ISBN 978-3-940369-77-2 (ONLINE) 